\title{
THE SOCIAL EDUCATOR'S ABILITIES OF REFLECTION ON PROFESSIONAL EXPERIENCE IN DIFFERENT STAGES OF ACTION
}

\author{
Remigijus Bubnys \\ Siauliai University, Lithuania \\ Ramunè Kiežaitė \\ Siauliai University, Lithuania
}

\begin{abstract}
The article presents tendencies of manifestation of skills forming social educators' abilities of reflection on professional experience and trends of their adaptability in different stages of action: reflection for action, reflection in action and reflection on action. Empirical data were collected employing a written survey method (using a structured closed type questionnaire). The data are analysed on the basis of the results of questionnaires filled in by 218 social educators. Descriptive statistics and multidimensional statistical methods (factor analysis) were applied. Research results disclose social educators' opinion about application of skills forming reflective abilities in professional activities in different stages of action (reflection for action, reflection in action and reflection on action), when the main element of the analysis is cognitive-evaluative aspect of reflection, evaluating possibilities and conditions of applying abilities in practical activities.
\end{abstract}

Keywords: experience, reflection, reflection skills, social educator, stages of action.

\section{Introduction}

In recent years, the problem of reflection/reflecting in the context of professional activity is becoming increasingly more relevant. Perception of reflection in professional activities, including the social educator's profession, starts with the understanding of what you are doing and is related to the ideas of learning from experience and lifelong learning. The ability to reflect in professional activities and creation of conditions for reflection enable to go deep into such areas as the analysis of personal professional experience, its improvement and justification, update and re-evaluation of knowledge, better cognising and managing oneself (Boud et al., 2005; Yip, 2006; Bolton, 2010 et al.). Reflection allows to diagnose personal mistakes, forming and improving effective experience analysis skills in action, for action and on action.

Developing Dewey's $(1933,1938)$ ideas, Schön $(1983 ; 1987)$ states that the specialist in his/her professional activity allows himself/herself to experience and cope with encountered challenges, novelties, confusion in situations, etc. While reflecting, professionals better know themselves, are able to look at the same problem from different perspectives, reflect both on positive and negative 
experiences, being able to choose suitable strategies, make adequate decisions both in professional activities and other life situations. Reflection abilities and their constituent skills are active efforts to create generalised knowledge of the self and the profession, encountering the dynamic environment of professional activities (Lam et al., 2007). No action in the professional activity gains its meaning if it is applied mechanically without consideration of previously accumulated experience and its interpretation. Therefore, it is relevant to create conditions for reflection, the essential elements of which are theoretical knowledge, experience, thinking, emotions, actions and values in the social context in which the person lives.

In the article, reflection on professional experience in professional activities is presented as a set of abilities and their constituent skills. Being a reflective social educator in professional activities means conditions to have and apply different abilities and skills forming the competence of reflection, constantly thinking of concerns, exploring them, giving a sense to them and interpreting one's experience, looking at the same problem from different perspectives, (Bradbury, 2010). The social educator's reflection in professional activities can be perceived as learning from experience, when the role and responsibility are changing in retrospect, thinking about the present and the future. Reflection on experience acquired in professional activities, including reflection for action, reflection in action and reflection on action, are presented in scientific literature (Schön, 1987; Cowan, 1998; Coulson \& Harvey, 2013; Comer, 2016 et al.) among basic abilities and constituent skills ensuring professional and personal development. Reflection for action, in action and reflection on action encompass epistemology of professional practice, grounded on cognition of activities and knowledge of actions. Reflection on various aspects of professional activities is effective, seeking quality of activities and knowledge update, solving difficulties (Hilden \& Tikkamäki, 2013). While reflecting social educators focus on practice, creation of new knowledge, cooperation with other people. It provides an advantage to disclose experiences, express one's thoughts, which often remain unnoticed in the immediate environment (Raelin, 2002). This way creating preconditions to better understand the identity of oneself as a professional, forming effective analytical skills in action, for action and on action. Based on given assumptions for importance of reflection abilities in professional activities, the following problem question of the research is formulated: which reflection skills are applied in different stages of social educators' professional activities (in action, for action and on action)?

The research object: manifestation of applicability of the social educator's professional experience reflection skills in different stages of activities. 
Research aim: to disclose applicability of the social educator's professional experience reflection abilities and their constituent skills in different stages of activities (reflection for action, in action and after action).

\section{Research Methodology}

The research sample. During the research 330 questionnaires were distributed; they were filled in by and the data were based on 218 (100 percent) social educators working in educational institutions in the whole Lithuania, of which 212 (97,2 percent) were females and 6 (2,8 percent), males. The selection of the sample is targeted, convenient.

Research methods. Data collection method: written survey, using a structured closed type questionnaire. Data processing method: statistical analysis of research data, applying descriptive statistics and multidimensional statistical methods (quantitative descriptive statistics of research data; multidimensional statistical method - factor analysis), using statistical data processing software SPSS 17.0 for Windows. Data processing was conducted applying exploratory factor analysis, which enables to identify the number of factors and their variables, seeking to understand from the latter what factors mean.

The research instrument. Research participants evaluated statements of the questionnaire (reflection skills in different stages of reflection: before, during and after action), selecting possible variants of answers: I did not experience; I experienced rarely; I experienced often, evaluating their practical work; i.e., how many possibilities they had to use their reflection abilities and their constituent skills in real-life professional activity situations.

\section{Research Results and their Discussion}

Conducted factor analysis of social educators' reflection skills enabled to distinguish factors representing separate groups of abilities with their constituent skills. Further, the results obtained in different stages of action - for action, in action and after action - are presented.

The pedagogue's abilities of reflection on professional experience for action. Having conducted factor analysis of statements, one factor manifestation of abilities of reflection on professional experience for action (see Table 1) - was distinguished. All variables of factors, amounting to eight, satisfy the condition $\mathrm{L} \geq 0,5$ and from the methodological standpoint are solid. Values of factor weights (L) range from high $(0,76)$ to moderate $(0,50)$. The KaiserMeyer-Olkin (KMO) coefficient value of the scale 0,84 indicates that variables are significantly interrelated. The scale is characterised by 37,11 percent 
dispersion and can be interpreted. The internal consistency coefficient of scale factors (subscales) Cronbach alpha $(\alpha)$ is 0,79 , indicating that the scale is homogeneous, with a high internal consistency level of scale criteria.

Table 1 The Social Educator's Ability of Reflection on Professional Experience for Action, \%

\begin{tabular}{|c|c|c|c|c|c|c|}
\hline \multirow[b]{2}{*}{ Skills } & \multicolumn{2}{|c|}{$\begin{array}{c}\text { I did not } \\
\text { experience }\end{array}$} & \multicolumn{2}{|c|}{$\begin{array}{l}\text { I experienced } \\
\text { rarely }\end{array}$} & \multicolumn{2}{|c|}{$\begin{array}{c}\text { I experienced } \\
\text { often }\end{array}$} \\
\hline & $\begin{array}{ll}\overrightarrow{0} & \dot{0} \\
0 & 0 \\
z & 0\end{array}$ & $\%$ & $\begin{array}{ll}\ddot{0} & \dot{0} \\
0 & \stackrel{0}{0} \\
z & \stackrel{0}{u}\end{array}$ & $\%$ & $\begin{array}{ll}\overrightarrow{0} & \dot{0} \\
0 & \stackrel{0}{0} \\
z & 0\end{array}$ & $\%$ \\
\hline $\begin{array}{l}\text { To identify information necessary for } \\
\text { performance of effective analysis of } \\
\text { professional experience }\end{array}$ & 14 & 6,4 & 70 & 32,1 & 134 & 61,5 \\
\hline $\begin{array}{l}\text { To select more of probable critically } \\
\text { evaluated alternative activities before } \\
\text { making a decision }\end{array}$ & 3 & 1,4 & 72 & 33,0 & 143 & 65,6 \\
\hline $\begin{array}{l}\text { To update one's possessed knowledge } \\
\text { based on acquired practical experience, } \\
\text { re-evaluating it anew }\end{array}$ & 3 & 1,4 & 56 & 25,7 & 159 & 72,9 \\
\hline $\begin{array}{l}\text { Planning activities, to link new } \\
\text { information with what was previously } \\
\text { known and experienced }\end{array}$ & - & - & 47 & 21,6 & 171 & 78,4 \\
\hline $\begin{array}{l}\text { To diagnose one's mistakes and } \\
\text { limitations of competence, learning to } \\
\text { manage one's emotions and behaviour }\end{array}$ & 14 & 6,4 & 107 & 49,1 & 97 & 44,5 \\
\hline $\begin{array}{l}\text { To justify how certain experience } \\
\text { formed, considering achieved results and } \\
\text { adapting them for the future }\end{array}$ & 7 & 3,2 & 90 & 41,3 & 121 & 55,5 \\
\hline $\begin{array}{l}\text { To engage in constant self-reflection on } \\
\text { one's activities before starting activities }\end{array}$ & 11 & 5,0 & 99 & 45,4 & 108 & 49,5 \\
\hline $\begin{array}{l}\text { Before making decisions, to use } \\
\text { colleagues' lived personal experience }\end{array}$ & 21 & 9,6 & 101 & 46,3 & 96 & 44,0 \\
\hline
\end{tabular}

The first factor reveals the reflection process, during which priorities for future activities are established by identifying needs, endeavours and goals for the future. The results disclose that the majority of social educators have possibilities and conditions to link new information with previously acquired experience while planning their activities. Social educators update their existing knowledge, re-evaluating it anew, justifying how experience formed. Almost half (49,5 percent) of social educators are engaged in permanent self-reflection on their activities before starting new activities; however, almost the same share of social educators indicate that in the stage of planning they rarely have possibilities to engage in self-reflection. A similar share of social educators 
(49,1 percent) state that they can rarely diagnose their mistakes and limitations of competence, learning to manage their emotions and behaviour.

Analyzing abilities of reflection for activity, it is important to distinguish the fact that reflection in the cooperation environment, as indicated by Cady et al., (1998), enables the professional's professional development; therefore, it is important to base oneself on experienced lived by others before making decisions; however, obtained results show that a significant share (46,3 percent) of educators rarely base themselves on their colleagues' lived personal experience before making decisions.

The social educator's abilities of reflection on professional experience in action. Factor analysis of skills to reflect professional experience in action resulted in three factors comprising three different abilities of reflection in action and their constituent skills. All variables of factors, having eliminated statements that did not meet the condition $\mathrm{L} \geq 0,5$ are solid from the methodological standpoint. The Kaiser-Meyer-Olkin (KMO) coefficient value of the scale 0,87 indicates that variables are significantly interrelated and the matrix is well-suited for factor analysis. The dispersion of 52,43 percent (from $22,87 \%$ to $13,07 \%$ ) characteristic to the scale indicates that all factors explain at least 10 percent of dispersion and can be interpreted. The internal consistency coefficient of scale factors (subscales) Cronbach alpha $(\alpha)$ ranges from 0,69 to 0,80 , indicating that the scale is homogeneous, with a high internal consistency level of scale criteria.

The content of the first factor the ability of causal relations and managing personal changes includes skills emphasising possibilities of identifying causal relations and factors influencing behaviour as well as personal changes in action. The results obtained during the research enable to state (see Table 2) that during reflection in action the majority (64,7 percent) of social educators have the possibility to analyze lived experience, relating it to possessed theoretical knowledge and thorough activity analysis.

Table 2 The Ability of Causal Relations and Managing Personal Changes in Action, \%

\begin{tabular}{|c|c|c|c|c|c|c|}
\hline \multirow{2}{*}{ Skills } & \multicolumn{2}{|c|}{$\begin{array}{c}\text { I did not } \\
\text { experience }\end{array}$} & \multicolumn{2}{|c|}{$\begin{array}{c}\text { I experienced } \\
\text { rarely }\end{array}$} & \multicolumn{2}{|c|}{$\begin{array}{c}\text { I experienced } \\
\text { often }\end{array}$} \\
\hline & $\begin{array}{ll}\dot{0} & \dot{0} \\
\circ & 0 \\
\mathbf{Z}\end{array}$ & $\%$ & $\begin{array}{ll}\ddot{0} & \dot{0} \\
\circ & 0 \\
\dot{2}\end{array}$ & $\%$ & $\begin{array}{ll}\dot{0} & \dot{0} \\
\circ & 0 \\
\dot{2} & 0\end{array}$ & $\%$ \\
\hline $\begin{array}{l}\text { To analyze lived experience, discovering } \\
\text { links with possessed theoretical } \\
\text { knowledge, concepts }\end{array}$ & 10 & 4,6 & 67 & 30,7 & 141 & 64,7 \\
\hline $\begin{array}{l}\text { To find causal relations and factors } \\
\text { influencing behaviour during the analysis } \\
\text { of experience }\end{array}$ & 5 & 2,3 & 90 & 41,3 & 123 & 56,4 \\
\hline
\end{tabular}




\begin{tabular}{|l|c|c|c|c|c|c|}
\hline $\begin{array}{l}\text { To engage in constant self-reflection of } \\
\text { one's activity in action }\end{array}$ & 7 & 3,2 & 85 & 39,0 & 125 & 57,3 \\
\hline $\begin{array}{l}\text { To change personal beliefs and } \\
\text { assumptions, which directly influence } \\
\text { performed actions during the activity }\end{array}$ & 21 & 9,6 & 105 & 48,2 & 92 & 42,2 \\
\hline
\end{tabular}

In their professional activities, social educators have least possibilities to change such personal beliefs and assumptions that directly affect performed actions in action. 41,3 percent of educators rarely have conditions to apply the skill during the analysis of experience in order to discover causal relations and factors influencing behaviour.

The content of the second factor the ability of activity evaluation and sharing personal experience in action includes experiences of applying acquired experience, skills of critical reflection and analysis of one's ideas in action. High results obtained during the research (see Table 3) disclose possibilities of applying abilities of performance evaluation and sharing personal experience in action in social educators' professional activities.

Table 3 The Ability of Performance Evaluation and Sharing Personal Experience in Action, \%

\begin{tabular}{|c|c|c|c|c|c|c|}
\hline \multirow{2}{*}{ Skills } & \multicolumn{2}{|c|}{$\begin{array}{l}\text { I did not } \\
\text { experience }\end{array}$} & \multicolumn{2}{|c|}{$\begin{array}{l}\text { I experienced } \\
\text { rarely }\end{array}$} & \multicolumn{2}{|c|}{$\begin{array}{l}\text { I experienced } \\
\text { often }\end{array}$} \\
\hline & 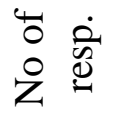 & $\%$ & 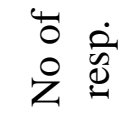 & $\%$ & $\begin{array}{ll} & \dot{0} \\
0 & 0 \\
0 & 0\end{array}$ & $\%$ \\
\hline $\begin{array}{l}\text { To reflect on exiting experience, sharing } \\
\text { it with colleagues }\end{array}$ & 2 & 0,9 & 41 & 18,8 & 175 & 80,3 \\
\hline $\begin{array}{l}\text { To reflect on and analyze possible } \\
\text { consequences of one's performed actions } \\
\text { during the activity }\end{array}$ & 4 & 1,8 & 50 & 22,9 & 164 & 75,2 \\
\hline To make complex decisions in action & 2 & 0,9 & 40 & 18,3 & 176 & 80,7 \\
\hline $\begin{array}{l}\text { To constantly purposefully update } \\
\text { knowledge, using various information } \\
\text { sources }\end{array}$ & 3 & 1,4 & 41 & 18,8 & 176 & 79,8 \\
\hline
\end{tabular}

The majority of social educators in their professional activities often have possibilities to make complex decisions (80,7 percent), reflect on and analyze current experience together with their colleagues (80,3 percent) and using various information sources, update their possessed knowledge (79,8 percent), because, as indicated by Pollard (2006), reflective activities are almost always more valuable if they are performed, thought over and analyzed together with colleagues. 
The ability of recognising attitudes and feelings in action of the third factor includes skills of recognising feelings, analysis of causes and dissociating oneself from prejudices (see Table 4).

Table 4 The Ability of Recognising Attitudes and Feelings in Action, \%

\begin{tabular}{|c|c|c|c|c|c|c|}
\hline \multirow{2}{*}{ Skills } & \multicolumn{2}{|c|}{$\begin{array}{c}\text { I did not } \\
\text { experience }\end{array}$} & \multicolumn{2}{|c|}{$\begin{array}{l}\text { I experienced } \\
\text { rarely }\end{array}$} & \multicolumn{2}{|c|}{$\begin{array}{l}\text { I experienced } \\
\text { often }\end{array}$} \\
\hline & $\begin{array}{ll}\text { Oे } & \dot{2} \\
0 & 0 \\
z & 0\end{array}$ & $\%$ & 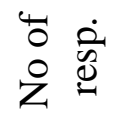 & $\%$ & 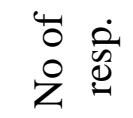 & $\%$ \\
\hline $\begin{array}{l}\text { To recognize feelings arising during } \\
\text { professional experience }\end{array}$ & 7 & 3,2 & 83 & 38,1 & 128 & 58,7 \\
\hline $\begin{array}{l}\text { To dissociate oneself from prejudices } \\
\text { and decisions in action }\end{array}$ & 9 & 4,1 & 96 & 44,0 & 113 & 51,8 \\
\hline $\begin{array}{l}\text { To explain reasons of decisions made in } \\
\text { action }\end{array}$ & 6 & 2,8 & 89 & 40,8 & 123 & 56,4 \\
\hline
\end{tabular}

The results demonstrate that the majority of social educators often find themselves in situations in action, when they can recognize feelings arising during professional experience (58,7 percent) and explain reasons of decisions made $(56,4$ percent). This fact is also verified by the analysis of scientific sources, as the ability to perceive emotions, cognize and analyze one's feelings is one of the main constituents of the reflection process (Salzberger-Wittenberg et al., 1999). It should be noted that a significant share (44,0 percent) of educators rarely manage to dissociate themselves from prejudices and decisions in action.

The social educator's abilities of reflection on professional experience after performed action. Having performed factor analysis of statements, two factors were distinguished. Values of factor weights (L) in factors range from high $(0,81)$ to moderate $(0,51)$. The Kaiser-Meyer-Olkin (KMO) coefficient value of the scale 0,90 indicates that variables are very significantly interrelated and the matrix is well-suited for factor analysis. The scale is characterized by 50,55 percent (from 25,96 to 24,59 percent) dispersion indicating that all factors explain at least 10 percent of dispersion and can be interpreted. The internal consistency coefficient of scale factors (subscales) Cronbach alpha $(\alpha)$ ranges from 0,82 to 0,84 , indicating that the scale is homogeneous, with a high internal consistency level of scale criteria.

The content of the ability of applying acquired experience, updating of and giving a sense to knowledge of the first factor includes skills of giving a sense to performed activities, planning of actions and reflection on results (see Table 5). 
Table 5 The Ability of Application of Acquired Experience, of Updating of and Giving a Sense to Knowledge, \%

\begin{tabular}{|c|c|c|c|c|c|c|}
\hline \multirow{2}{*}{ Skills } & \multicolumn{2}{|c|}{$\begin{array}{c}\text { I did not } \\
\text { experience }\end{array}$} & \multicolumn{2}{|c|}{$\begin{array}{l}\text { I experienced } \\
\text { rarely }\end{array}$} & \multicolumn{2}{|c|}{$\begin{array}{c}\text { I experienced } \\
\text { often }\end{array}$} \\
\hline & $\begin{array}{ll}\tilde{0} & \dot{2} \\
0 & 0 \\
z & 0\end{array}$ & $\%$ & 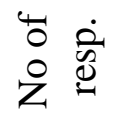 & $\%$ & 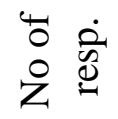 & $\%$ \\
\hline $\begin{array}{l}\text { Having solved the problem, to integrate } \\
\text { and reflect on knowledge and experience, } \\
\text { creating personal theories and } \\
\text { understanding }\end{array}$ & 4 & 1,8 & 70 & 32,1 & 144 & 66,1 \\
\hline $\begin{array}{l}\text { To use results of the analysis of lived } \\
\text { professional experience planning future } \\
\text { actions }\end{array}$ & 3 & 1,4 & 57 & 26,1 & 158 & 72,5 \\
\hline $\begin{array}{l}\text { To constantly purposefully update } \\
\text { knowledge, using various information } \\
\text { sources after the activity }\end{array}$ & 2 & 0,9 & 45 & 20,6 & 171 & 78,4 \\
\hline $\begin{array}{l}\text { To analyze one's behaviour after } \\
\text { performed activities, evaluating quality } \\
\text { of achieved performance results }\end{array}$ & 2 & 0,9 & 46 & 21,1 & 170 & 78,0 \\
\hline $\begin{array}{l}\text { To give a sense to one's professional } \\
\text { experience, transforming it into } \\
\text { knowledge, skills, attitudes and values }\end{array}$ & 6 & 2,8 & 49 & 22,5 & 163 & 74,8 \\
\hline $\begin{array}{l}\text { To set priorities for future activities, } \\
\text { identifying needs, endeavours and goals }\end{array}$ & 3 & 1,4 & 39 & 17,9 & 176 & 80,7 \\
\hline
\end{tabular}

Research results demonstrate that social educators are provided with conditions in their professional activities to successfully implement their skills of reflection for action. Based on the results of the performed activity, the majority ( 80,7 percent) of social educators establish priorities for future activities, identifying needs, endeavours and goals. 78,4 percent of respondents often purposefully update their possessed knowledge after performed activities, using various information sources after activities. Slightly less (72,5 percent) social educators have possibilities to plan their future actions on the basis of the already lived professional experience. Social educators have least possibilities in their professional activities to integrate and reflect on knowledge and experience upon solving the problem, creating personal theories and understanding.

The content of the ability of improvement of professional activities and implementation of novelties of the second factor includes skills of professional performance evaluation, justification, improvement and of implementation of novelties (see Table 6). 
Proceedings of the International Scientific Conference. Volume III, May $27^{\text {th }}-28^{\text {th }}$, 2016. 260-270

Table 6 The Ability of Professional Performance Improvement and Implementation of Novelties, $\%$

\begin{tabular}{|c|c|c|c|c|c|c|}
\hline \multirow{2}{*}{ Skills } & \multicolumn{2}{|c|}{$\begin{array}{c}\text { I did not } \\
\text { experience }\end{array}$} & \multicolumn{2}{|c|}{$\begin{array}{l}\text { I experienced } \\
\text { rarely }\end{array}$} & \multicolumn{2}{|c|}{$\begin{array}{l}\text { I experienced } \\
\text { often }\end{array}$} \\
\hline & 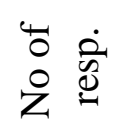 & $\%$ & 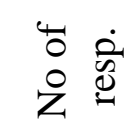 & $\%$ & $\begin{array}{ll}\text { पे } & \dot{0} \\
0 & \stackrel{0}{0}\end{array}$ & $\%$ \\
\hline $\begin{array}{l}\text { To evaluate advantages and shortcomings } \\
\text { of professional activities, foreseeing } \\
\text { professional development perspectives }\end{array}$ & 4 & 1,8 & 58 & 26,6 & 156 & 71,6 \\
\hline $\begin{array}{l}\text { To diagnose one's mistakes and } \\
\text { limitations of competence after } \\
\text { performed activities }\end{array}$ & 5 & 2,3 & 73 & 33,5 & 139 & 63,8 \\
\hline $\begin{array}{l}\text { To justify how certain experiences } \\
\text { formed, having evaluated achieved } \\
\text { results }\end{array}$ & 8 & 3,7 & 80 & 36,7 & 130 & 59,6 \\
\hline $\begin{array}{l}\text { To look for information necessary for } \\
\text { planning one's new professional } \\
\text { activities }\end{array}$ & 2 & 0,9 & 33 & 15,1 & 183 & 83,9 \\
\hline $\begin{array}{l}\text { To reflect on one's professional activity } \\
\text { in the past, transferring skills or avoiding } \\
\text { repetition of mistakes in the future }\end{array}$ & 3 & 1,4 & 64 & 29,4 & 151 & 69,3 \\
\hline $\begin{array}{l}\text { To identify activity problems, choosing } \\
\text { adequate ways and techniques of } \\
\text { solutions in the future }\end{array}$ & 1 & 0,5 & 66 & 30,3 & 151 & 69,3 \\
\hline $\begin{array}{l}\text { To improve one's professional life, based } \\
\text { on the results of the analysis of lived } \\
\text { practical experience }\end{array}$ & 2 & 0,9 & 44 & 20,2 & 172 & 78,9 \\
\hline
\end{tabular}

The majority of social educators often ( 83,9 percent) in their professional activities are looking for information necessary for planning their new activities in the future. Foreseeing their professional development prospects, social educators often evaluate advantages and drawbacks of their professional activities (71,6 percent) and reflecting on their performed professional activities in the past, use acquired experience in order to avoid repetition of mistakes in the future $(69,3$ percent). Attention should be drawn to the fact that more than one third of social educators in their professional activities rarely apply skills to diagnose their mistakes and limitations of competence after performed activities, to justify how certain experiences formed, having considered achieved results, and to identify performance problems, choosing adequate ways and techniques of solving them in the future. 


\section{Conclusions}

The analysis of tendencies of social educators' reflection abilities for action enables to conclude that planning and foreseeing new activities, in their professional activities social educators implement their abilities of reflection on action, emphasizing the importance of acquired practical experience, which is significant updating and re-evaluating possessed knowledge, relating new information to previously lived experience. During their professional activities social educators have possibilities to use abilities of reflection in action and reflection for action but they lack situations in which they have to change their personal beliefs and assumptions that directly affect actions in action and to critically evaluate their performed activities, justifying how certain experiences formed, having considered achieved results.

Social educators have real possibilities and conditions for using their abilities of reflecting in different stages of action in their professional activities; however, they often lack time, efforts or situations enabling to diagnose their mistakes and limitations of competence in order to reflect on their activities and behaviour. Presented research results disclose limitations of applying skills forming reflection abilities in practice as an assumption for further improvement of conditions and possibilities of professional activities. It is relevant to pay more attention to such possibilities of practical activities which would enable simulation of situations, in which the social educator could re-evaluate personal attitudes and values, justify acquired experience, considering achieved results, identifying performance problems, diagnose his/her mistakes and limitations of competence, learning to manage his/her emotions and behaviour.

\section{References}

Bolton, G. (2010). Reflective practice: writing and professional development. SAGE publications.

Boud, D., Keogh, R., \& Walker, D. (2005). Reflection: Turning Experience into Learning. London and New York: Routledge Falmer.

Bradbury, H. (2010). Beyond Reflective Practice: New Approaches to Professional Lifelong Learning. Routledge: London.

Cady, J., Distad, L., \& Germundsen, R. (1998). Reflective Practice Groups in Teacher Induction: Building Professional Community via Experiential Knowledge, Education, $118(3), 459-470$.

Comer, M. (2016). Rethinking reflection-in-action: What did Schön really mean? Nurse Education Today, 36, 4-6.

Coulson, D., \& Harvey, M. (2013). Scaffolding student reflection for experience-based learning: a framework. Teaching in Higher Education, 18 (4), 401-413.

Cowan, J. (1998). On Becoming an Innovative University Teacher. Buchingham: Open University. 
Proceedings of the International Scientific Conference. Volume III, May $27^{\text {th }}-28^{\text {th }}$, 2016. 260-270

Dewey, J. (1933). How We Think, Revised Edition. Boston: D.C. Heath.

Dewey, J. (1938). Experience in Education. New York: Collier Books.

Hilden, S., \& Tikkamäki, K. (2013). Reflective practice as a fuel for organizational learning. Administrative Sciences, 3 (3), 76-95.

Lam, C. M., Wong, H., \& Leung, T. F. (2007). An Unfinished Reflexive Journey: Social Work Students' Reflection on Their Placement Experiences. British Journal of Social Work, 37 (1), 91-105.

Pollard, A. (2006). Refleksyvusis mokymas. Veiksminga ir duomenimis paremta profesine praktika. Vilnius: Garnelis.

Raelin, J. A. (2002). „I don't have time to think!” versus the art of reflective practice. Reflections, 4 (1), 66-79.

Salzberger-Wittenberg I., \& Williams, G., Osborne, E. (1999). The Emotional Experience of Learning and Teaching. London: Karnac Books.

Schön, D. (1983). The Reflective Practitioner. San Francisco: Jossey-Bass.

Schön, D. (1987). Educating the Reflective Practitioner: Towards a New Design for Teaching and Learning in the Professions. San Fransisco: Jossey-Bass.

Yip, K. (2006). Self-reflection in Reflective Practice: A Note of Caution, British Journal of Social Work, 36 (5), 777-788. 